\title{
BIOLEACHING OF LOW GRADE NICKEL ORE USING INDIGENOUS FUNGI
}

\author{
PELINDIAN BIJIH NIKEL KADAR RENDAH MENGGUNAKAN \\ JAMUR INDIGENOS
}

\author{
SRI HANDAYANI and SURATMAN \\ R\&D Centre for Mineral and Coal Technology \\ Jalan Jenderal Sudirman 623 Bandung 40211 \\ Ph. (+6222) 6030483, Fax. (+6222) 6003373 \\ e-mail: sri@tekmira.esdm.go.id
}

\begin{abstract}
In this research, the biological leaching of nickel by indigenous fungi isolated from Indonesian limonite was studied to develop a feasible technique for microbial recovery of nickel from low grade nickel ore. XRD analyses indicated that goethite, alumina and quartz were major mineral composition of the ore. In the present study, isolated fungal strains having potential to solubilize nickel were characterized. that were identified as Aspergillus $s p$ and Penicillium $s p$ depending upon their colony morphology and microscopic studies. All microorganisms found were tested for organic acid production and leaching capabilities of nickel. Leaching experiments were performed in $250 \mathrm{ml}$ Erlenmeyer flask at room temperature and $150 \mathrm{rpm}$ agitation under aseptic conditions. It was observed that the Aspergillus $s p$ substantially leached more nickel from limonite compared to the Penicillium $s p$. Nickel solubilization was related to $\mathrm{pH}$ decrease and organic acid excreted caused by growth of fungi in medium containing glucose as carbon source. The mechanisms of nickel extraction had been examined either directly or indirectly related to fungal activity. The presence of fungal cells seems to improve the leaching process. However, the use of higher pulp density resulted in a decrease of nickel solubilization. The maximum nickel recovery was $57 \%$ at $5 \%$ pulp density after 20 days of direct leaching by Aspergillus sp.
\end{abstract}

Keywords: bioleaching, low grade nickel ore, indigenous fungi, Aspergillus sp, Penicillium sp

\begin{abstract}
ABSTRAK
Dalam penelitian ini, pelindian nickel oleh jamur indigenos yang diisolasi dari bijih limonit dipelajari untuk mengembangkan teknik ekstraksi logam tersebut dari bijih nikel kadar rendah. Analisis XRD menunjukkan komposisi mineral utama bijih terdiri atas goetit, alumina dan kuarsa. Strain fungi yang mempunyai potensi melarutkan nikel dikarakterisasi dan telah diidentifikasi sebagai Aspergillus sp dan Penicillium sp berdasarkan morfologi koloni dan studi mikroskopik. Percobaan pelindian dilakukan secara aseptik dalam $250 \mathrm{ml}$ labu erlenmeyer pada suhu kamar dan agitasi $150 \mathrm{rpm}$. Aspergillus sp melindi nikel lebih baik dan efisien dibandingkan Penicillium sp. Pelindian nikel berkaitan erat dengan penurunan $\mathrm{pH}$ dan produksi asam organik oleh pertumbuhan fungi dalam medium glukosa sebagai sumber karbon. Telah ditelaah mekanisme pelindian secara langsung dan tidak langsung. Keberadaan dan keterlibatan sel-sel fungi dapat meningkatkan proses pelindian nikel. Namun pelindian dalam persen padatan yang lebih tinggi menurunkan ekstraksi nikel. Maksimum ekstraksi nikel sebesar 57\% diperoleh pada pelindian secara langsung oleh Aspergillus sp menggunakan 5\% padatan selama 20 hari.
\end{abstract}

Kata kunci: bioleaching, bijih nikel kadar rendah, jamur indigenos, Aspergillus sp, Penicillium sp 


\section{INTRODUCTION}

Nickel has played a central role in global industrial development. With a demand growth at approximately $4-5 \%$ per annum for the last five years, nickel consumption has outpaced most other industrial metals. Nickel primary use is in the production of stainless steel that accounts for approximately $60 \%$ of global demand for primary nickel and therefore, high stainless steel demand will indirectly increase the demand for nickel. The rapid urbanization in the developing nations has led to a huge demand for stainless steel products. China has been the major driver for the increase in global production and is expected to continue to play a major role in the next five years (GLENCORE, 2016).

In recent years, Indonesia has consistently ranked among the top ten global producers of nickel (Kuck, 2015). Its world-class mines are Pomalaa and Sorowako and active mining companies include PT Vale and PT Antam (Blevich, 2015). The country is a key supplier of nickel to Asia's leading industrialized and industrializing nations. Nickel mining is a significant contributor to Indonesia's GDP and the major contributor to the GDP of a number of its provinces (Widajatno, 2011).

Nickel occurs in nature in two forms: sulphides (high grade ores) and laterites (low grade ores). The majority of the world's known nickel resources (about 70\%) are contained in laterites, making it significant as the future supply of nickel. However, their large stockpiles of low grade ores yet to be mined (Ashcroft, 2016). The recovery of metals from them using conventional techniques is very expensive because of high energy and capital costs required. Another problem is that environmental costs due to high level of pollution from conventional technologies will continue to rise.

Bioleaching is regarded as one of the most promising solutions to these problems, compared to the chemical leaching (Watling, 2016). It holds the promise of dramatically reducing the capital costs. It also offers the opportunity to reduce environmental pollution. Bioleaching processes are carried out under mild condition without adding toxic chemicals. The products of biological processes end up in aqueous solution which is easier to containment and treatment.
Therefore, the final objective of this bioleaching is to produce nickel from low grade ores with less energy utilization and more environmentally friendly process.

Bioleaching is basically the dissolution of metals from their ores under the influence of microorganisms leading to the yield of metal solution of leach liquor containing metals. Metals such as nickel, cobalt, copper, zinc, manganese can be extracted by bioleaching process (Ahmadi et al., 2015). Several microorganisms such as bacteria and fungi have been used for different ores. The ability of microorganisms to leach and mobilize metals from solid material comprises of three principles: redox reactions, formation of organic or inorganic acids, and/or excretion of complexing agents. Although the amenability of nickel laterite mineral to bioleaching process has been demonstrated by many researchers (Simate, Ndlovu and Walubita, 2010; Bazgha, Haq and Sadia, 2011; Mubarok, Astuti and Chaerun, 2012; Audenaerde, 2013; Biswas et al., 2013; Chiang et al., 2014; Ghosh and Paul, 2016), but there still remains a considerable amount of basic research to be conducted before its application economically. The successful of microbial growth and easy maintenance are the keys to the successful of bioleaching and this is the interest of this study area.

The objective of this present study is to isolate indigenous microorganism capable of dissolving nickel metals contained in the lateritic ores. The obtained microorganism then utilized for leaching the nickel ores, to study the bioleachability of metal values and to elucidate the dissolution behavior of the laterites ores in bioleaching process.

\section{METHODOLOGY}

\section{Ore Material}

The laterite ores used in this study was limonite ore from Pomalaa, South East Sulawesi. Sample of this low grade nickel ore was subjected to acid digestion using concentrated hydrochloric acid, and the percentage of nickel, cobalt and other metals were determined by Atomic Absorption Spectrophotometer. Mineralogy of the lateritic nickel ore was analysed using synchrotron-based high-resolution X-ray diffraction (XRD). 


\section{Microorganisms}

Microorganisms were isolated from the ore through serial dilution of ore suspension on Potato Dextrose Agar plates. Predominant, morphologically distinct colonies were selected and isolated by repeated subculturing. Isolates were identified by their colony characteristics, spores morphology and microscopic observations. Two of these "wild strains" microorganism were tentatively identified as Aspergillus $s p$ and Penicillium $s p$. Both fungi strains were tested for their feasibility of extracting nickel from low grade nickel ores.

The heavy metal tolerance training used for adapting the fungi was based on gradual acclimatization involving serial sub-culturing of the fungi to the ore. Acclimatization was conducted in Petri dishes containing agar growth medium with $2 \%$ original ore. Fungal cultures were preserved at $4^{\circ} \mathrm{C}$ in PDA agar slants and they were sub cultured every 2 weeks. Spore suspension of 7 days old culture was used as inoculum.

\section{Direct Bioleaching}

Bioleaching of $5 \mathrm{~g}$ limonite ore samples was carried out in $250 \mathrm{ml}$ Erlenmeyer flask that contained $100 \mathrm{ml}$ medium. The medieum consisted of $(\mathrm{g} / \mathrm{L})$ : glucose $50, \mathrm{NH}_{4} \mathrm{NO}_{3} 3$, $\mathrm{KH}_{2} \mathrm{PO}_{4}, 0.5 ; \mathrm{MgSO}_{4} .7 \mathrm{H}_{2} \mathrm{O} 0.5$, and yeast extract 1.2. The $\mathrm{pH}$ value of solution was adjusted with $2 \mathrm{M} \mathrm{NaOH}(\mathrm{pH} 6)$, buffered with Tris $1 \mathrm{M}$ at the beginning of incubation, and then sterilized at $121^{\circ} \mathrm{C}$ for 30 minutes. The submerged culture media were inoculated with $5 \mathrm{ml}$ inoculum (a spore suspension of fungi at concentration of $2 \times 10^{6}$ spores $/ \mathrm{ml}$ ) under aseptic condition. The number of spore was determined using Neubauer counting chamber. The flasks were incubated at room temperature on a rotary shaker at $150 \mathrm{rpm}$ for 20 days. Simultaneous organic acid production and nickel leaching occurred over that period of time, and was assessed by sampling and analysis. The 3-ml samples, removed from the flasks for analysis, were replaced with fresh nutrient solution to maintain constant volume in the experimental suspensions. The amount of oxalic and citric acids, $\mathrm{pH}$ of medium, and concentration of released nickel ions were measured and determined every day. The abiotic control in the absence of fungi was incubated under the same condition. After incubation, the culture solution were separated from the biomass by means of filtration.

The fungal strains were also examined for assessing the effects of pulp density on nickel extraction as a function of period of leaching. The experiments were conducted at different pulp density of 5,10 and $15 \%$ $(w / v)$. All other conditions were the same. Samples were taken at regular intervals (every day) for analysis of nickel by AAS.

\section{Indirect Bioleaching}

Indirect bioleaching is bioleaching of limonite ore using metabolite-lixiviants produced by fungi. For production of metabolite containing oxalic and citric acid, fungi were cultivated in 1-L Erlenmeyer flask containing $500 \mathrm{ml}$ of medium with media growth composition as mentioned above, but in the absence of limonite ore. After 10-days of cultivation, the medium separated by filtration and the fungifree supernatant were used as a leaching agents for bioleaching process. The absence of the microorganisms in the fungi-free supernatant was verified by inoculation in the medium. No growth was observed even after 48 hours of incubation. Bioleaching of the $5 \mathrm{~g}$ limonite samples then was carried out using $100 \mathrm{ml}$ of the metabolite in the $250 \mathrm{ml}$ of Erlenmeyer flask. The leaching process was performed at $150 \mathrm{rpm}$ at room temperature for 14 days. The concentration of nickel ions generated from the ore into the solution was measured every day. All experiments were carried out in duplicates and the reported values were the average values. The maximum deviation from the average value was found to be less than $5 \%$.

\section{Analytical Measurements}

The amount of oxalic produced by fungi was determined using a spectrophotometer at 525 Milton Roy Spectronic based on the method developed by Bergermann and Elliot; and citric acid was determined by the tritation method of Marrier and Boulet. An Atomic Absorption Spectrophotometer instrument Shimadzu AA 680 was used to determine the concentration of nickel ions in the liquid samples that were taken during the leaching process and in the mineral characterization studies. 


\section{RESULTS AND DISCUSSION}

\section{Characterization of Limonite Ore}

Analysis result of XRD presented in Figure 1 revealed that the predominant minerals in limonite ore sample were goethite-a hydrated iron oxide $(\mathrm{FeOOH})$, alumina $\left(\mathrm{Al}_{2} \mathrm{O}_{3}\right)$ and quartz $\left(\mathrm{SiO}_{2}\right)$. The ore was a complex, soft, and agglomerate of highly porous fine particles of very high surface area. The ore was grinded and sieved to $-150+200$ mesh. Percentages of nickel and other metal oxides were determined by Atomic Absorption Spectrophotometer and the result is shown in Table 1.

\section{Direct Bioleaching}

The bioleaching results of nickel extraction by Aspergillus $s p$ and Penicillium $s p$ after 20days leaching are presented in Table 2, and Figure 2. Aspergillus sp leached substantially better compared to Penicillium sp. In this study, Aspergillus $s p$ was found more efficient in nickel extraction compared to Penicillium $s p$. This may due to high leaching activity of organic acids excreted by Aspergillus $s p$ in the culture media and subsequently dissolve nickel by forming salts and chelates. As shown in Table 2, Aspergillus sp produced more organic acids and therefore dissolved more nickel.
Figure 2 shows profile of nickel extraction over 20-days direct leaching at 5\% pulp density. The nickel extraction by Aspergillus $s p$ was insubstantial up to the $4^{\text {th }}$ day of leaching due to less organic acid generation which was obvious from $\mathrm{pH}$ values of around 5 (Figure 3 ). It appeared that rapid nickel leaching occurred after 7 days. The final extraction of nickel by Aspergillus sp was $57 \%$ during 16 days of leaching at $\mathrm{pH}$ 2.2. For Penicillium sp, this trend was similar but suggested more delay of about 7 days before the nickel was leached more fast, and the final recovery of nickel was only $48 \%$ at $\mathrm{pH} 2.6$ after 18-days leaching.

Table 1. Chemical composition of the ore sample

\begin{tabular}{cc}
\hline Component & Wt.\% \\
\hline $\mathrm{SiO}_{2}$ & 1.72 \\
$\mathrm{NiO}$ & 1,66 \\
$\mathrm{Al}_{2} \mathrm{O}_{3}$ & 9.02 \\
$\mathrm{Fe}_{2} \mathrm{O}_{3}$ & 49,8 \\
$\mathrm{Co}_{2} \mathrm{O}_{3}$ & 0.19 \\
$\mathrm{MgO}$ & 5,04 \\
$\mathrm{MnO}$ & 1,10 \\
$\mathrm{CaO}$ & 0,41 \\
$\mathrm{Na}_{2} \mathrm{O}$ & 0,18 \\
\hline
\end{tabular}

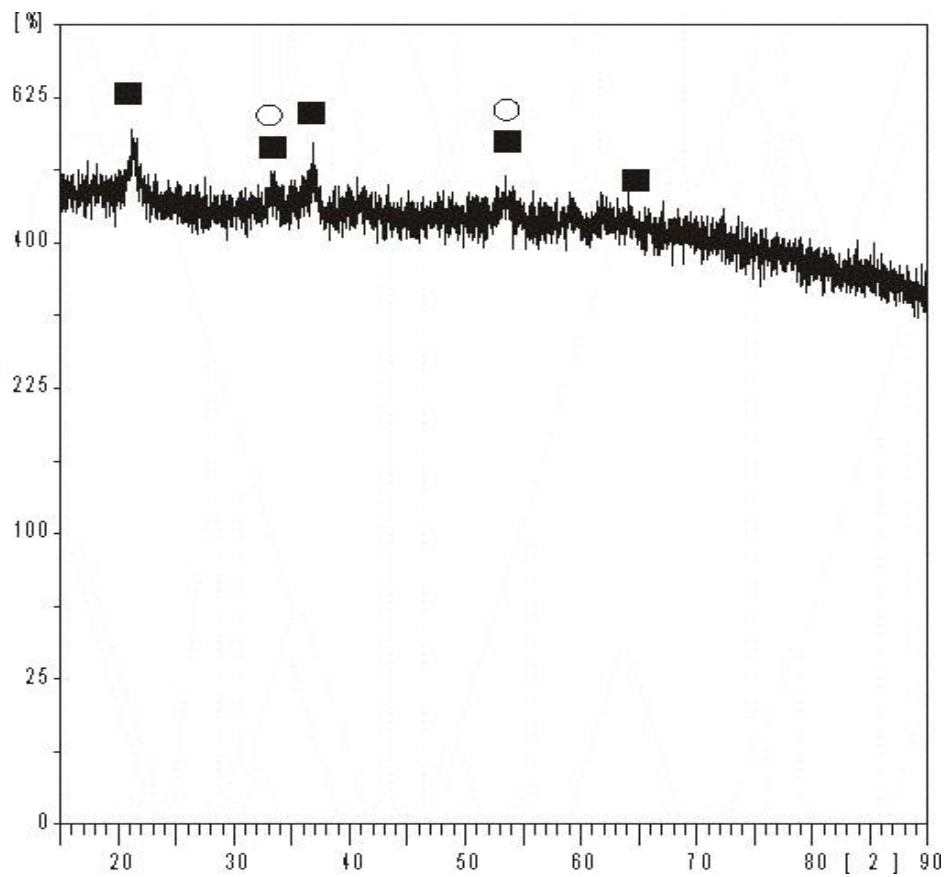

Figure 1. XRD analysis result of limonite ore sample: (匹) goethite-limonit, $(\mathrm{O})$ quartz 
Table 2. Extraction of nickel from limonite ore by "wild type" strains of Aspergillus $s p$ and Penicillium sp after 20-days direct leaching at 5-\% pulp density.

\begin{tabular}{lcccc}
\hline Fungal strains & Extracted Ni $(\%)$ & $\begin{array}{c}\text { Citric acid } \\
\text { produced }(\mathrm{g} / \mathrm{L})\end{array}$ & $\begin{array}{c}\text { Oxalic acid } \\
\text { produced }(\mathrm{g} / \mathrm{L})\end{array}$ & $\begin{array}{c}\text { Final } \mathrm{pH} \\
\text { in medium }\end{array}$ \\
\hline Aspergillus $s p$ & 57 & 23 & 21 & 2.2 \\
Penicillium $s p$ & 48 & 15 & 12 & 2.6 \\
\hline
\end{tabular}



Figure 2. Nickel extraction by direct leaching at 5-\% pulp density

Nickel ions were generated into the solution during leaching process. It can also be seen that the dissolution rate gradually increased as the organic acid concentration in solution increased and the $\mathrm{pH}$ decreased. After 14 days, the organic acid concentration and the solubilization rate remained stable. The sigmoid form of the curves and the strong relationship between organic acid concentration, $\mathrm{pH}$ and rate of nickel extraction indicated that the reaction of nickel solubilization was catalyzed by $\mathrm{pH}$ and the organic acid generated into the solution. It is suggested that the highest nickel extraction corresponds with the maximum in organic acid production by the fungi.

An increase in acid production for a longer period of time resulted in an increase in nickel solubilization. Effect of initial $\mathrm{pH}$ of media on fungal growth (Figure 3) shows that Aspergillus $s p$ and Penicillium $s p$ have followed similar growth pattern in their growth. Both fungi had shown good biomass growth when the incubation started at $\mathrm{pH} 6$. It has also been observed that the $\mathrm{pH}$ of the media is continuously decreasing with the biomass growth. The relative neutral $\mathrm{pH}$ at the beginning for all growth experiments with fungi turned to acidic at the end of bioleaching process. The $\mathrm{pH}$ after 20 days of leaching ranged from 2.2 to 2.6 .

Nickel solubilization was accompanied by a decrease in the $\mathrm{pH}$ of the medium by both the fungal strains. Aspergillus $s p$ solubilized $57 \mathrm{mg} / \mathrm{L}$ of nickel with a decrease in $\mathrm{pH}$ from 6.0 to 2.2 in 16 days. Penicillium sp solubilized $48 \mathrm{mg} / \mathrm{L}$ of nickel in 18 days with $\mathrm{pH}$ falling from 6.0 to 2.6. Aspergillus $s p$ shows much higher drop in $\mathrm{pH}$, higher organic acid production, and simultaneous higher nickel solubilization when compared to Penicillium sp. The results under these experimental conditions show a noticeable improvement compared to study done by Mubarok, Astuti and Chaerun (2012) who obtained a maximum $24,5 \%$ of nickel extraction from Indonesian (Pomalaa) low grade limonite ore using Aspergillus niger. 
INDONESIAN MINING JOURNAL Vol. 19, No. 3, October $2016: 143$ - 152

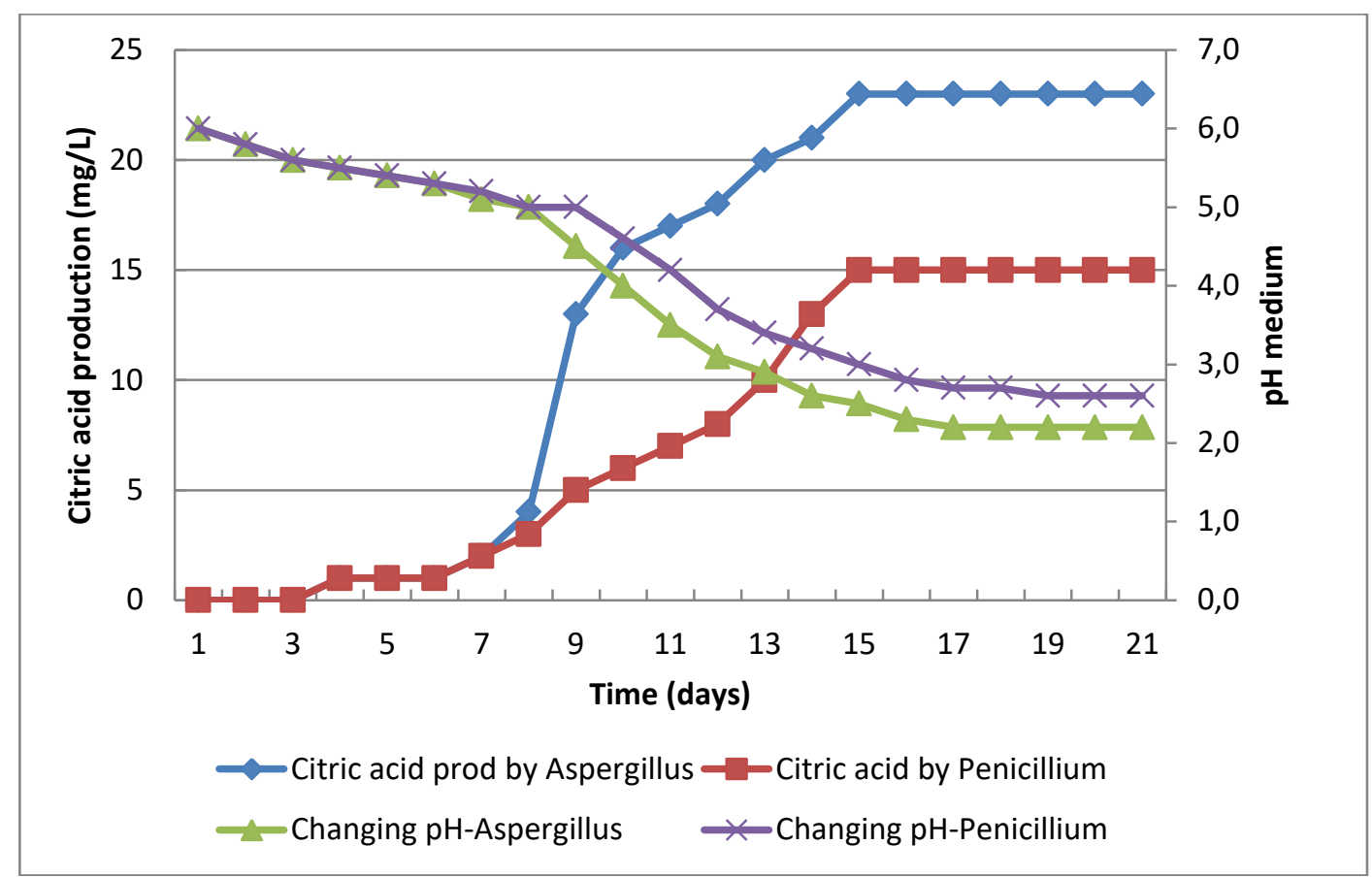

Figure 3. Changing $\mathrm{pH}$ and organic acids excreted by Aspergillus sp and Penicillium sp in direct bioleaching at $5-\%$ pulp density

As reported previously, fungi are capable to mobilize metals by formation of organic acids such as citric and oxalic acids, oxidation/reduction reactions, extraction of complexing agents and chelates formations. The production of citric and oxalic acid by fungi can be written as follows:

$\mathrm{C}_{6} \mathrm{H}_{12} \mathrm{O}_{6}+4.5 \mathrm{O}_{2} \rightarrow 3 \mathrm{C}_{2} \mathrm{H}_{2} \mathrm{O}_{4}$ (oxalic acid) + $3 \mathrm{H}_{2} \mathrm{O}$

$\mathrm{C}_{6} \mathrm{H}_{12} \mathrm{O}_{6}+1.5 \mathrm{O}_{2} \rightarrow 3 \mathrm{C}_{6} \mathrm{H}_{8} \mathrm{O}_{7}$ (citric acid) + $2 \mathrm{H}_{2} \mathrm{O}$

According to Bohidar, Mohapatra and Sukla (2009), acid leaching can be expressed by this equation:

$\mathrm{NiO}+2 \mathrm{H}^{+} \rightarrow \mathrm{Ni}^{2+}+\mathrm{H}_{2} \mathrm{O}$

Complexation or chelation of $\mathrm{Ni}$ with citric acid:

$\mathrm{Ni}^{2+}+\mathrm{H}_{3}$ (citrate) $\rightarrow \mathrm{Ni}$ (citrate) $+3 \mathrm{H}^{+}$

Precipitation by oxalic acid:

$\mathrm{Ni}^{2+}+\mathrm{HO}_{2} \mathrm{C} \cdot \mathrm{CO}_{2} \mathrm{H} \rightarrow \mathrm{Ni}\left(\mathrm{O}_{2} \mathrm{C} \cdot \mathrm{CO}_{2}\right)(\mathrm{S})+2 \mathrm{H}^{+}$

Organic acids occupy a central position in the overall process and supply both protons and metal complexing organic acid anion.
Behera, Sukla and Mishra (2010) reported that citric acid $\left(\mathrm{C}_{6} \mathrm{H}_{8} \mathrm{O}_{7}\right)$ receives its acidity from three groups of carboxylic $\mathrm{COOH}$ which can release proton in the aqueous solution and resulted in citric ions. Citric acid can react with nickel ions to form soluble nickel-citrate ligand complex by chelating mechanism. In addition, Coto et al. (2016) showed complexation of metals with citric acid excreted by Aspergillus as seen in Figure 4.

\section{Indirect Bioleaching}

The nickel recovery obtained from direct and indirect bioleaching processes are compared. The results are presented in Table 3. Aspergillus sp leached $57 \%$ nickel in direct leaching after 20 days compared to $48 \%$ in indirect bioleaching. For Penicillium $s p$, the same extraction were only 48 and $39 \%$ respectively. The difference in the nickel solubilization in the presence and the absence of fungi was considerable higher indicating the efficiency of microorganisms. This results suggest that the nickel bioleaching did not result simply from the biochemical leaching of bio-acids secreted by the fungi, but fungal cells appeared to participate in the leaching process. Therefore, bio-acids appeared to be used 
more effective in the present of the fungal cells as shown by greater order of magnitude results. Fungi were more effective in direct nickel bioleaching because of the production of citric and oxalic acid together with other organic metabolites such as amino acids, proteins, protons and peptides. Cell particle contact may contribute to the enhancement of fungal bioleaching by stimulating more organic acid production as demonstrated by Bohidar, Mohapatra and Sukla (2009).

\section{Effect of Pulp Density}

A series of experiments was conducted with leach suspensions containing varying amounts of nickel ore to assess their effects on nickel extraction. The pulp density had a great influence on the solubilization rate of nickel. Figure 5 illustrates the effect of pulp density on nickel dissolution from limonite using Aspergillus $s p$ and Penicillium $s p$. It was observed that the percentage of nickel extraction increased with the duration or residence time for any fixed pulp density. Meanwhile, the extraction rate of nickel was noted to decrease with increasing pulp density from 5 to $10 \% \mathrm{w} / \mathrm{v}$. The rate and extent of nickel extraction declined sharply with further increase in pulp density of $15 \%$ $w / v$. Optimal nickel dissolution in limonite as shown in Figure 5 occurred at a pulp density of $5 \mathrm{wt} \%$. Additional reduction in ore load did not improve metal recovery. Meanwhile, the solubilized nickel in the sterile controls were $80 \%$ lower than those obtained during inoculated runs.

This factor has been found to be indirectly related to the rate of mineral solubilization. Increasing substrate concentration tended to inhibit fungal leaching. It was possible that with these increases, heavy metals concentrations became high enough to be inhibitory to the metabolic activity of the fungi. Similar observations was reported by Ahmadi et al. (2015) who compared the bioleaching rates at two different pulp densities of 5 and $10 \%$ and concluded that the former produced a better leaching of $\mathrm{Ni}$ from low grade sulfidic tailing of Golgohar iron mine. Therefore, these findings could be attributed to the earlier presumptions the adverse effect of low fungi-to-solid ratio and the inhibitory effect of increasing concentration of heavy metals ions at high pulp density although these fungi strains in the present study had been presumably adapted to the high concentration of heavy metals containing in the ores. This linear trend indicates the inability of the fungal strains to efficiently drive the dissolution of the ore beyond their limit. However, at the present time, no very obvious explanation can be given for this phenomenon yet.

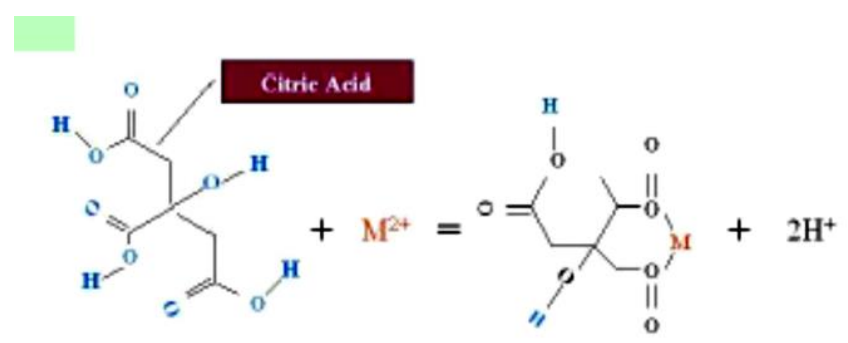

Figure 4. Complexation of metal by citric acid (Coto et al., 2016)

Table 3. Comparison of nickel extraction by direct and indirect bioleaching

\begin{tabular}{ccc}
\hline \multirow{2}{*}{ Fungal strains } & \multicolumn{2}{c}{ Extracted Ni (\%) } \\
\cline { 2 - 3 } & Direct leaching & Indirect leaching \\
\hline Aspergillus $s p$ & 57 & 48 \\
Penicillium $s p$ & 48 & 39 \\
\hline
\end{tabular}


INDONESIAN MINING JOURNAL Vol. 19, No. 3, October 2016 : 143 - 152

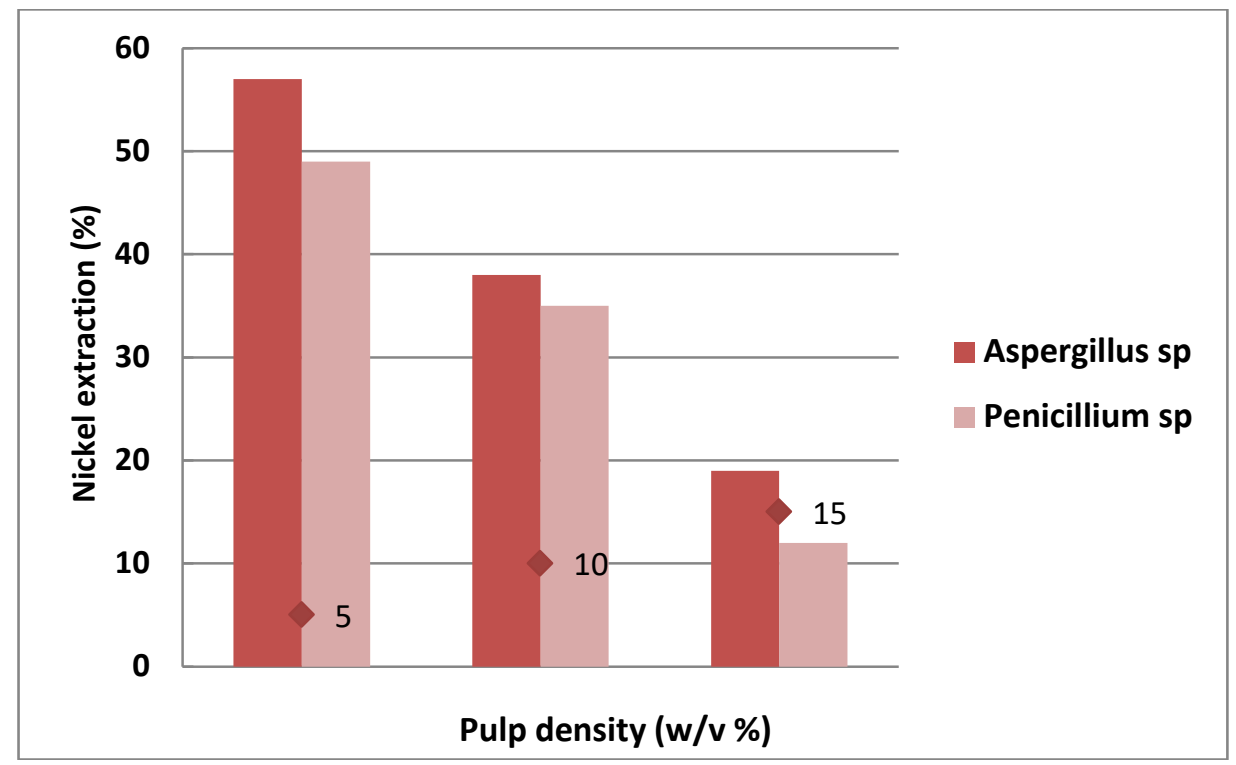

Figure 5. Nickel recovery from limonite with varying pulp density after 20-days direct bioleaching

\section{Discussion}

Assuming time is not a factor (such as the case in mine wastes or using waste materials) and a very cheap carbon source could be provided (Ali et al., 2016), the fungi could compete with chemical reagents as candidates in nickel bioleaching. Besides that, fungi can grow in higher $\mathrm{pH}$ environments and can be used at approximately room temperature, $26-30^{\circ} \mathrm{C}$ (Addo et al., 2016). In addition, the production of organic acids, amino acids, proteins, protons and peptides by fungi increases the solubility of metals in solutions, thereby aiding in the bioleaching process. Nevertheless, prior to the full development of a technology where fungi could be used as bioleaching agents, the immediate focus should be on intensive adaptation and further enhancement of their leachability. Indeed, there should also be investigations into different methods in which minerals could be leached with these fungi, bearing in mind the ease of separation of the fungi and mineral products after leaching, as well as the cost implication of the methods should be low. For instance, the consequence of direct leaching with the fungi should be investigated more detail and compared further to the use of fungal filtrates for the leaching process for easier process and handling.
A difficult challenge regarding the use of fungi in bioleaching will be the growth of the fungi under non-sterile conditions. The $\mathrm{pH}$ and temperature ranges at which fungi grow normally supports the growth of many contaminants. Furthermore, the use of fungi in bioleaching could be feasible if there is well understanding of the metabolic pathways and genetics of these fungi.

In the application, the production of citric acid could be combined with the leaching of a nickel-containing ore. Both nickel metal and the acid consuming nickel are dissolved, and after nickel metal recovery, the nickel citrate is either sold as is, or converted into citric acid. The conversion of citric acid can be accomplished in a number of ways, such as ion exchange and electrodialysis.

Citric acid (2-hydroxy-1,2,3 propane tricarboxylic acid) is one of the few fine chemicals that are produced by fermentation (Singh et al., 2016). Citric acid is an intermediate metabolic product of oxidative dissimilation of sugar and it is produced through the formation of pyruvic acid. To accumulate citric acid as the main or only product, the process should regulating the $\mathrm{pH}$ or adding a specific enzyme inhibitor to the medium. The addition of a basic material such as lime can regulate the $\mathrm{pH}$. 
In citrate synthesis, biomass growth is the critical factor as uncontrolled growth results in poor yields. Investigations have shown that the optimum $\mathrm{pH}$ for growth is 6.0 and for citrate production around 2-3. Therefore, the process is preferably conducted in a $\mathrm{pH}$ range from about 2 to 6 . Initial $\mathrm{pH}$, temperature, concentration and type of organic carbon, as well as nutrients such as nitrogen, phosphate and trace elements play important roles in maximizing yields. The concentration of citric acid in the fermentation broths is governed by the initial amounts of organic carbon. The only expense is the rather long batch fermentation period of about 8-14 days. In a continuous systems, this time might be substantially reduced.

\section{CONCLUSIONS AND SUGGESTIONS}

The present study demonstrated the effective role and the potential efficiency of isolated "wild type" fungi in the extraction of nickel from limonite. From the results obtained it was confirmed that low grade nickel ore was amenable to bioleaching using indigenous fungi. Aspergillus $s p$ seems to be more efficient in nickel leaching compared to Penicillium $s p$. In a shake flask experiments carried out at $5 \%$ pulp density showed maximum nickel extraction of $57 \%$. Organic acids produced by the fungi along with other metabolites which were yet to be established seems were responsible for bioleaching of nickel. Under this experimental conditions, indirect bioleaching using organic acids as lixiviants was less effective compared to direct bioleaching.

This study worked with glucose as carbon source. Working with different media formulation may result in complex and variable behaviour with the organism and these effects are subjects for continuing detailed study. In any industrial application, this source would need to be derived from an inexpensive waste material. These results indicate the challenges but also the promising aspects of bioleaching as an alternative process for recovery of nickel from low grade nickel ore in the near future.

\section{ACKNOWLEDGEMENTS}

The work described in this paper was supported in part by R\&D Centre for Mineral and Coal Technology and is gratefully acknowledged. The authors wish to thank the staffs of Chemistry Laboratory, who helped analysing this research. The authors also wish to express gratitude to Dr. Andang Setiawan, Bandung Institute of Technology, for his support and valuable discussions.

\section{REFERENCES}

Addo, M. G., Kusi, A., Andoh, L. A. and ObiriDanso, K. (2016) "Citric acid production by Aspergillus niger on a corn cob solid substrate using one-factor-at-a-time optimisation method," IARJSET, 3(1), pp. 95-99. doi: 10.17148/IARJSET.2016.3120.

Ahmadi, A., Khezri, M., Abdollahzadeh, A. A. and Askari, M. (2015) "Bioleaching of copper, nickel and cobalt from the low grade sulfidic tailing of Golgohar Iron Mine, Iran," Hydrometallurgy, 154, pp. 1-8. doi: 10.1016/j.hydromet.2015.03.006.

Ali, S. R., Anwar, Z., Irshad, M., Mukhtar, S. and Warraich, N. T. (2016) "Bio-synthesis of citric acid from single and co-culturebased fermentation technology using agro-wastes," Journal of Radiation Research and Applied Sciences, 9(1), pp. 57-62. doi: 10.1016/j.jrras.2015.09.003.

Ashcroft, G. (2016) Nickel laterites: The world largest source of nickel, Geology for Investors. Available at: http://www.geologyforinvestors.com/nick el-laterites/.

Audenaerde, V. (2013) An extraction sustainable nickel from olivine via carbonation and bioleaching treatments. KU Leuven, Belgium.

Bazgha, A., Haq, N. B. and Sadia, I. (2011) "Bioextraction of metal ions from laterite ore by Penicillium chrysogenum," African Journal of Biotechnology, 10(54), pp. 11196-11205. doi: 10.5897/AJB11.1296. 
Behera, S. K., Sukla, L. B. and Mishra, B. K. (2010) "Leaching of nickel laterite using fungus mediated organic acid and synthetic organic acid: A comparative study," in Proceedings of the XI International Seminar on Mineral Processing Technology, pp. 946-954.

Biswas, S., Dey, R., Mukherjee, S. and Banerjee, P. C. (2013) "Bioleaching of nickel and cobalt from lateritic chromite overburden using the culture filtrate of Aspergillus niger," Applied Biochemistry and Biotechnology, 170(7), pp. 1547-1559. doi: 10.1007/s12010-013-0289-9.

Blevich (2015) The Indonesian nickel industry Strategic market prospects out to 2020. Metal Bulletin Research.

Bohidar, S., Mohapatra, S. and Sukla, L. B. (2009) "Nickel recovery from chromite overburden of Sukinda using fungal strains," International Journal of Integrative Biology, 5(2), pp. 103-107.

Chiang, Y. W., Santos, R. M. Dos, Van Audenaerde, A., Monballiu, A., Van Gerven, T. and Meesschaert, B. (2014) "Chemoorganotrophic Bioleaching of Olivine for Nickel Recovery," Minerals, 4(2), pp. 553-564. doi: $10.3390 / \min 4020553$.

Coto, O., Cabrera, G., Hernadez, I., Cantero, D. and Gomez, J. M. (2016) Bioleaching of laterite tailings by strains of Aspergillus niger. University of Havana.

Ghosh, S. and Paul, A. K. (2016) "Bioleaching of nickel by Aspergillus humicola SKP102 isolated from Indian lateritic overburden," Journal of Sustainable
Mining, 15(3), pp. 108-114. doi: 10.1016/j.jsm.2016.11.002.

GLENCORE (2016) Nickel market development; Present: Improved market condition.

Kuck, P. H. (2015) Nickel. US Geological Survey. Mubarok, M. Z., Astuti, W. and Chaerun, S. K. (2012) "Leaching behaviour of nickel from Indonesian laterite ore in some organic acids," in Proceedings of XIII International Mineral Processing Symposium (IMPS 2012), pp. 523-531.

Simate, G. S., Ndlovu, S. and Walubita, L. F. (2010) "The fungal and chemolithotrophic leaching of nickel laterites - Challenges and opportunities," Hydrometallurgy, 103(14), pp. 150-157. doi: 10.1016/j.hydromet.2010.03.012.

Singh, P., Draboo, S., Singh, A., Chaturvedi, S., Sharma, S. and Verma, P. (2016) "Citric acid production from different sources under submerged conditions using Aspergillus niger," International Journal of Current Microbiology and Applied Sciences, 5(5), pp. 483-492. doi: 10.20546/ijcmas.2016.505.050.

Watling, H. (2016) "Microbiological Advances in Biohydrometallurgy," Minerals, 6(2), p. 49. doi: 10.3390/min6020049.

Widajatno, D. (2011) "The Indonesian mineral mining sector: Prospects and challenges," in German-Indonesia Mining Technology Symposium. Jakarta, pp. 1-42. 